Ann. Biol. anim. Bioch. Biophys., 1978, 18 (2 B), 453-460.

\title{
Differential response of components of sheep Graafian follicles to atresia
}

\author{
by Mary F. HAY, D. G. CRAN
}

Agriculfural Research Council, Instifute of Animal Physiology, Animal Research Station, 307 Huntingdon Rood,

Cambridge CB3 0JQ, U.K.

Summary. No structural difference can be detected between granulosa and cumulus cells of non-atretic ovine follicles less than $5 \mathrm{~mm}$ in diameter. In larger follicles numerous intracellular granules characterize the base of the cumulus. During primary and secondary atresia the cumulus, unlike the granulosa, remains largely unaffected. The oocyte remains in the germinal vesicle stage and retains full developmental capacity. In severely affected follicles the cumulus breaks down releasing the oocyte which may be abnormal. During atresia the volume occupied by the inner capillary network of the theca interna decreases. It is suggested that this may be involved in the atretic process.

\section{Introduction.}

The ovarian follicle is a balanced physiological unit whose function depends not only on extra-follicular factors such as gonadotrophins but also on a complex system of intra-follicular relationships. For example, the oocyte has been reported to prevent luteinization of the granulosa cells (Nekola and Nalbandov, 1971), while the granulosa plays a role in inhibiting resumption of meiosis by the oocyte (Foote and Thibault, 1969) ; furthermore, a close relationship between the granulosa and the theca is required for normal steroidogenic function of the follicle (Moor, 1977).

During atresia a sequence of degenerative changes occurs that has a differential effect on the various follicular components. Over the last 60 years numerous histological studies have been made on atretic follicles in a variety of species (for references, see Ingram, 1962 ; Jones, 1970 ; Greenwald, 1974). Some have concentrated on the changes in the follicle wall, others on the fate of the oocyte. The majority of authors agree that in antral (Graafian) follicles the earliest morphological signs of atresia are seen in the granulosa cells, and furthermore, it is widely accepted that follicles may start to become atretic at any stage in their development (see Greenwald, 1974). However, in very few studies is it possible to determine at exactly what stage in the atretic process degeneration of the oocyte commences. In this paper, in an attempt to gain further insight into intrafollicular relationships, the differential effects of atresia on the various components of the ovine follicle will be described. 


\section{Material and methods.}

Follicles over $2 \mathrm{~mm}$ were dissected from ovaries of sheep between day 4 and 14 of the cycle and rapidly fixed either in Bouin's fluid or in glutaraldehyde and processed as described previously (Hay, Cran and Moor, 1976). An area adjacent to the cumulus of those follicles immersed in the former fixative was marked with carbon to aid subsequent histological examination. The area of follicle wall containing the cumulus was processed separately for those fixed in glutaraldehyde.

After having been sectioned, all follicles were examined for atresia and graded as described previously (Hay, Cran and Moor, 1976) ; areas containing all follicular components were examined.

\section{Observations and discussion.}

The relationship between granulosa and cumulus cells.

The granulosa cells lining the antrum of Graafian follicles and the cumulus cells surrounding the oocyte have a common origin, both being derived from the follicle cells of unilaminar follicles (see e.g. Zamboni, 1972). Follicles are continually recruited from this pool of non-growing primordial follicles and enter the growing population ; the follicle cells proliferate, follicular fluid is secreted and an antrum is formed. It is only at this time that the two compartments of granulosa and cumulus may be distinguished.

Mitotic activity within the granulosa is such that a constant thickness is maintained during much of follicular growth. The mitotic rate in the cumulus is greater resulting in its growth. This is accompanied by the formation of a reticulum of lacunae few of which have egress to the antrum (Hay, Cran and Moor, 1976).

In non-atretic follicles the granulosa and cumulus cells have a similar structure as seen both at the level of the light and the electron microscope. Both compartments contain two morphological types; basal columnar cells and above these several

\section{PLATE 1}

FIG. 1. - Cumulus of large follicle from an untreated sheep on day 10 of the oestrous cycle. Note the presence of darkly staining granules adjacent to the basal lamina $(\times 120)$.

FIG. 2. - Enlargement of part of figure 1 showing the infra-cellular bodies $(\times 460)$.

FIG. 3. - Part of the adjacent wall of the same follicle as in figure 1 demonstrating the relative paucity of bodies in this region $(\times 615)$.

FIG. 4. $-2 \mathrm{~mm}$ afretic follicle in which part of the granulosa has stripped off $(\times 25)$.

FIG. 5. - Cumulus of the follicle in figure 4 showing the maintenance of cellular integrity and the presence of a vesicular nucleus $(\times 150)$.

FIG. 6. - Degenerative granulosa of the same follicle as shown in figure 4. Compare with figure $5(\times 235)$. 
PLATE 1
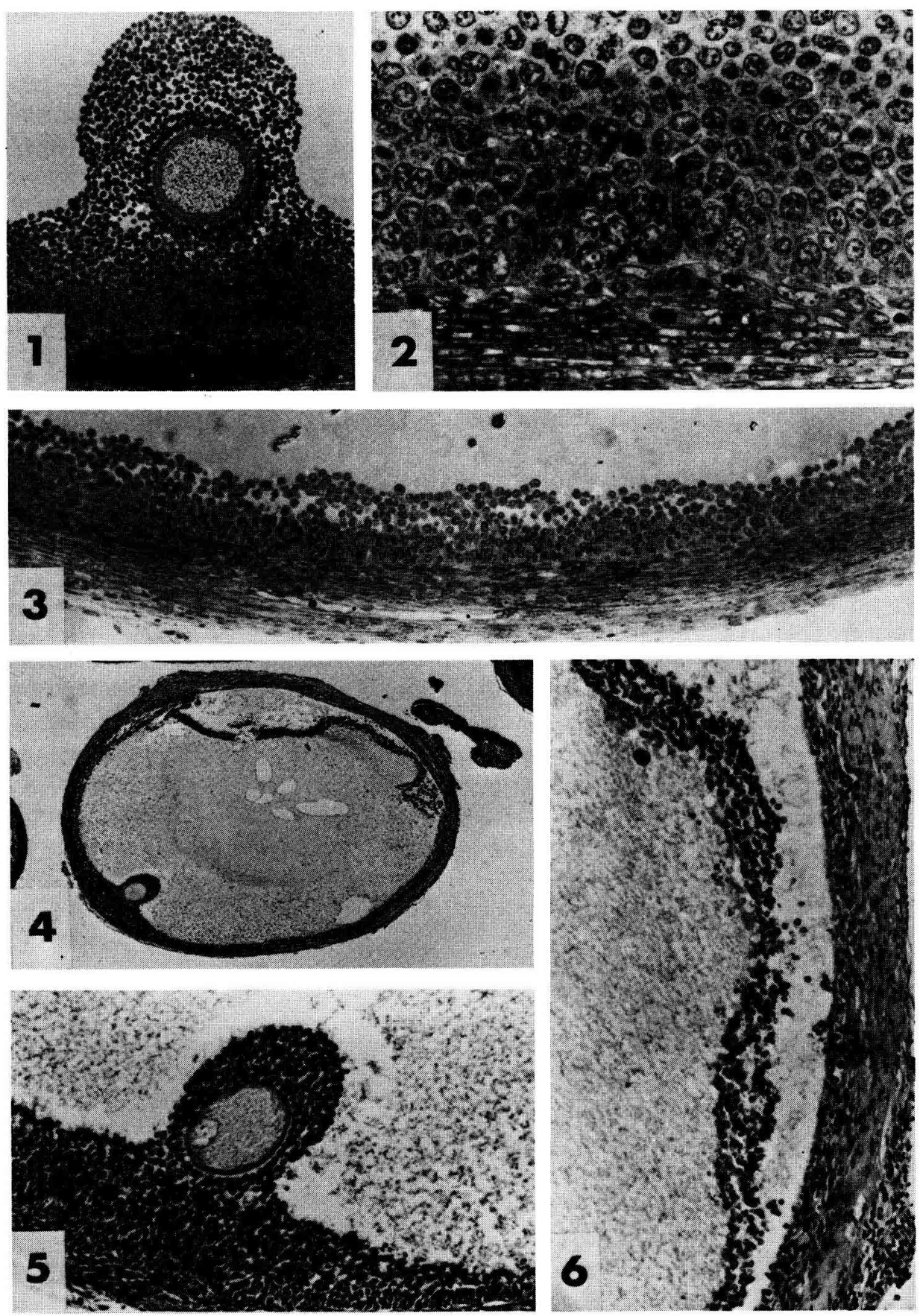
layers of more rounded cells with larger intercellular spaces. Thus, at least in small and medium-sized antral follicles ( $<5 \mathrm{~mm}$ diam.) there appear to be a considerable degree of similarity between the cells comprising the granulosa nd the cumulus.

In larger follicles there are structural indications of a difference between cumulus cells and mural granulosa cells. Individual cells in the basal layer often contain numerous, large, osmiophilic membrane bound bodies (figs. 1-3). Such cells are particularly frequent in the cumulus although they may occasionally be found in the granulosa. The presence of these bodies appears to be related to follicle and cumulus size. They are found throughout the cycle in the larger follicles, most of which are destined to become atretic, as well as in the pre-ovulatory follicle. The nature of these organelles in unknown. Histochemical tests do not reveal any acid phosphatase or aryl sulphatase activity and thus there is no positive evidence to indicate that they have any clearly defined lysosomal role. However, the frequency with which they occur does suggest that they may have an important function.

The effect of atresia on granulosa cells.

In the sheep the first signs of atresia are always detected in the granulosa (Hay, Cran and Moor, 1976). Degenerate cells with pyknotic nuclei, free pyknotic nuclei and vacuoles are present along the antral border and an area of cellular disorganization can often be detected some two or three cell layers from the basal lamina. As atresia advances these features become much accentuated such that in fertiary atresia a majority of the cells are degenerate. Atretic bodies (equivalent to free or fused pyknotic nuclei) of varying sizes are numerous and the entire inner layers of the granulosa may be sloughed off into the antrum.

It is somewhat surprising that in follicles showing such widespread degeneration the basal lamina separating the theca interna from the granulosa remains unbroken. In addition, a few granulosa cells remain which, as judged by their ultrastructural appearance, are viable. Such cells may be found in close apposition to areas of gross degeneration. It is clear, therefore, that all cells in the granulosa are not equally affected by the atretic process.

If such follicles are cultured, regeneration of the granulosa commences within 24-36 hr (Hay and Moor, 1978). By $72 \mathrm{hr}$ the thickness of the granulosa is double that of non-atretic follicles similarly cultured. It seems clear that the source of the granu-

\section{PLATE 2}

FIG. 7. - Cumulus of an atretic follicle with some internal pyknosis $(\times 225)$.

FIG. 8. - Higher magnification of oocyte shown in figure 7. Many processes penetrate the zona $(\times 485)$.

FIG. 9. - Cumulus of a highly atretic follicle. The cumulus has largely disintegrated and the oocyte and surrounding cells lie free in the antrum $(\times 180)$.

FIG. 10. - Degenerate oocyle shown in figure 9. The processes do not penetrate the zona. Compare with figure $8(\times 485)$. 
PLATE 2
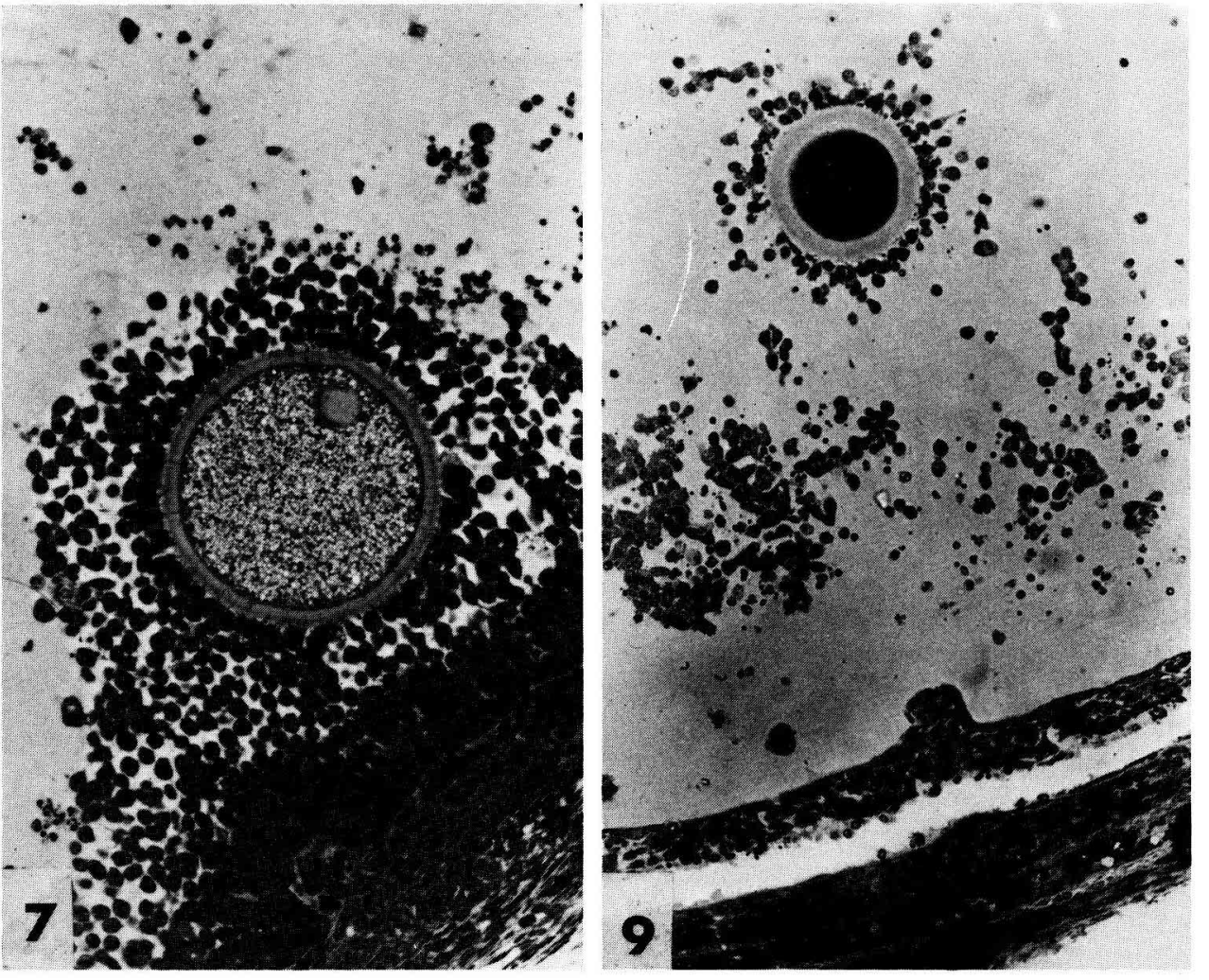

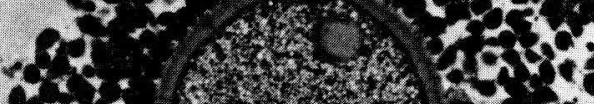
5.2

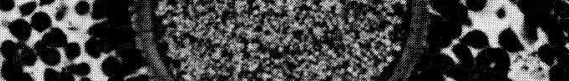
2030: $-2 x^{2}+x^{2}+2 x+4$ की

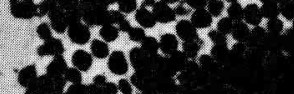

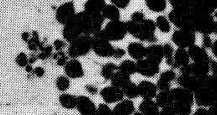

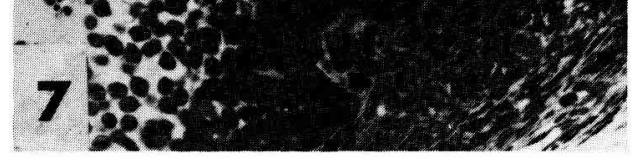
(2)

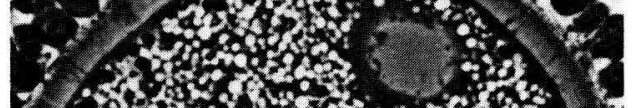

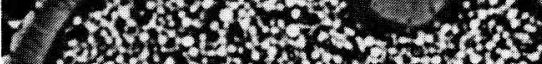

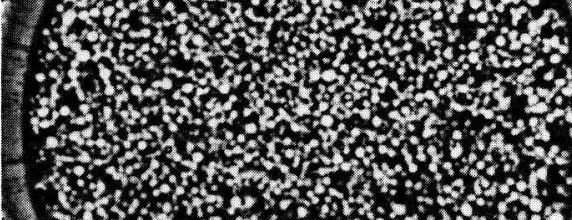

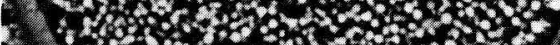

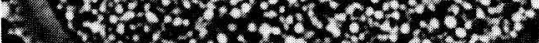

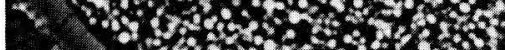
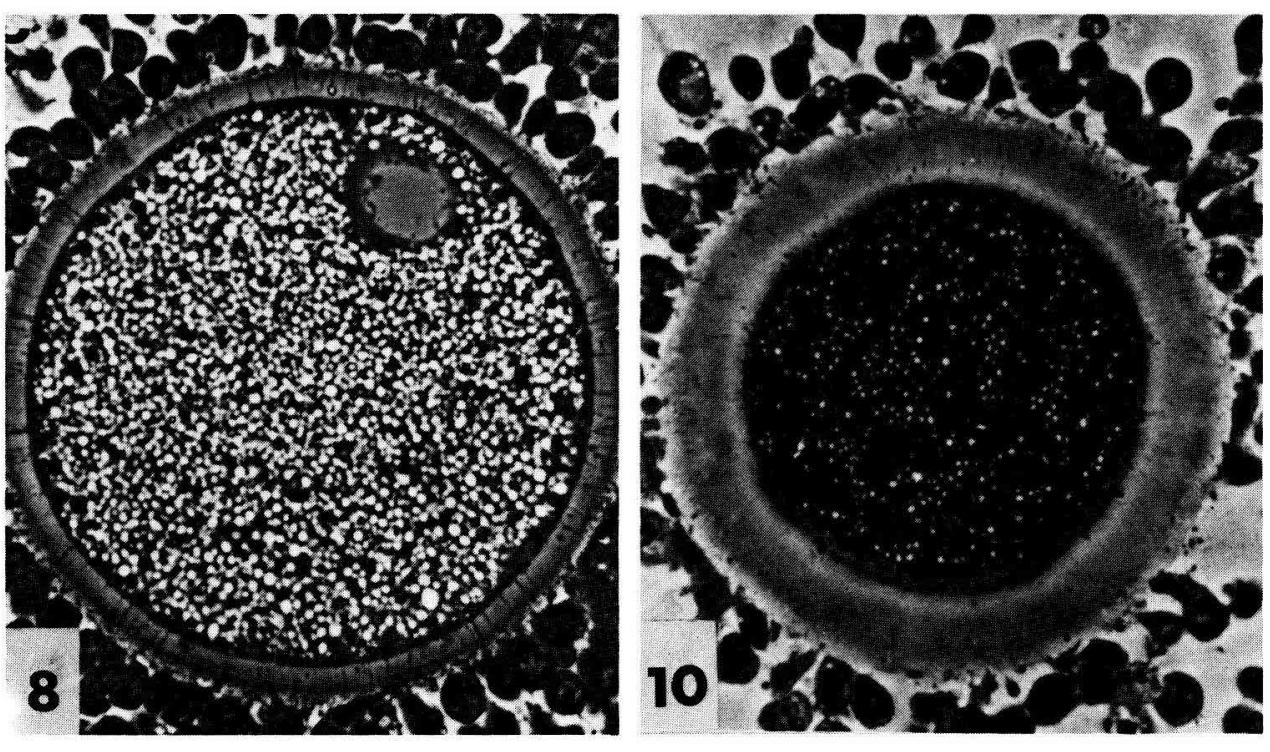
losa cells that proliferate in the atretic follicles in culture is those granulosa cells that escape the damaging effects of the atretic process.

\section{Effect of atresia on cumulus-oocyte complex.}

In follicles in primary and secondary stages of atresia there is a clear distinction between the degenerating granulosa cells and the cumulus cells which at this stage are still actively dividing and show no sign of any involutionary change. Even during tertiary atresia (figs. 4-6), the cumulus in some follicles shows no sign of necrosis; in others there are degenerate cells with pyknotic nuclei within the cumulus mass. As atresia advances, the cumulus eventually breaks up and the oocyte, with a few cumulus cells attached to it, is set free within the antral cavity (fig. 9).

During primary and secondary atresia, the oocytes remain in the germinal vesicle stage and are in all respects structurally similar to oocytes in non-atretic follicles. When pyknotic nuclei first appear in the cumulus during tertiary atresia the oocyte is usually in the germinal vesicle stage and processes from the surrounding cumulus cells can clearly be seen penetrating the zona (figs. 7 and 8). However, as degeneration of the cumulus progresses, oocytes are found in which germinal vesicle breakdown has occurred, some of these oocytes being in metaphase I or II. In such oocytes processes no longer penetrate the zona, these either having been withdrawn or having degenerated (fig. 10). Fragmentation of the follicular oocyte, reported in atretic follicles of many species (Dempsey, 1939) is an extremely rare event in the sheep in follicles more than $2 \mathrm{~mm}$ diameter.

Viability of oocytes in atretic follicles.

It has recently been shown that when ovine oocytes are cultured within ovarian follicles for $24 \mathrm{hrs}$ in a medium containing gonadotrophins and oestrogen they not only resume meiosis, but also undergo full physiological maturation (Moor and Trounson, 1977). Such oocytes can be fertilized and develop to term when transferred to suitable recipient ewes. Moor and Trounson (1977) examined the viability of oocytes in atretic follicles during secondy and tertiary stages of atresia and found that $50 \mathrm{p} .100$ of these oocytes had the capacity for normal embryonic development, as compared with 46 p. 100 of oocytes from large non-atretic follicles. These figures are remarkably high when compared with the value of about 70 p. 100 commonly obtained when freshly ovulated eggs are transferred (Moor, personal communication).

Effects of atresia on thecal compartment.

Degeneration within the theca interna is not as dramatic as that seen in the granulosa. However, preliminary observations in a current study suggest that the thecal tissue undergoes some changes that parallel those occurring in the granulosa (O'Shea, unpublished observations).

A marked difference with regard to the area occupied by the inner capillary network and the number of erythrocytes contained therein has been observed (Hay, Cran and Moor, 1976). In a morphometric analysis it was found that the area of the inner network of atretic follicles was only about one third of that of non-atretic follicles 
and the number of observable erythrocytes was 85 p. 100 less. It would appear, therefore, that the granulosa in such follicles is subjected to a substrate limitation and it is tempting to suggest that this is a causative factor of the atretic process.

\section{Concluding remarks.}

Remarkably little information is available in the literature on the relative state of degradation present in the various follicular components during the process of atresia. In the sheep, and also in the cow (Rajakoski, 1960), the cumulus appears to occupy a priviledged position in comparison with the adjoining membrana granulosa. A factor contributing to this distinction may be preferential vascularization of that part of the theca which is in close proximity to the cumulus. It is not known whether the cumulus shows a similar relative resistance to atresia in other species.

Study of atresia in sheep ovarian follicles (Hay, Cran and Moor, 1976 ; Moor and Trounson, 1977) has shown clearly that widespread degeneration of the granulosa is compatible with maintenance of the oocyte in the germinal vesicle stage and furthermore that oocytes in atretic follicles can retain full developmental capacity. During atresia the complex system of gap junctions within the granulosa and cumulus complex must be interrupted, but apparently without serious deleterious effect upon the oocyte. However it seems likely that germinal vesicle breakdown may occur when atresia progresses to the stage at which the close spatial relationship between healthy cumulus cells and the oocyte is lost.

$27^{\mathrm{e}}$ Congrès international des Sciences physiologiques,

Symposium « Germ and somatic cell interaction »

Paris, 21-23 juillet 1977.

Résumé. Chez la brebis aucune différence de structure ne peut être mise en évidence entre les cellules de la granulosa et les cellules du cumulus des follicules non atrétiques de moins de $5 \mathrm{~mm}$ de diamètre. Dans les follicules plus grands, la présence de nombreux granules caractérise les cellules de la base du cumulus. Pendant les phases primaires ef secondaires de l'atrésie, les cellules du cumulus restent en grande majorité normales, contrairement à celles de la granulosa. Les ovocytes demeurent au stade de la vésicule germinative ef gardent toute leur capacité de développement. Dans les follicules très atteints, le cumulus se rompt, libérant l'ovocyłe qui peut être anormal. Au cours de l'atrésie, le volume occupé par le réseau capillaire profond de la thèque interne subit une décroissance qui doit être impliquée dáns les processus de l'atrésie.

\section{References}

DEMPSEY E. W., 1939. Maturation and cleavage figures in ovarian ova. Anat. Rec. 75, 223-235.

FOOTE W. D., THIBAULT C., 1969. Recherches expérimentales sur la maturation in vitro ovocyles de truie et de veau. Ann. Biol. anim. Bioch. Biophys., 9, 329-349.

GREENWALD G. S., 1974. Role of follicle-stimulating hormone in follicular development and ovulation, 293-325. In GREIGER S. R., Handbook of Physiology, sect. 7, Endocrinology vol, IV, part. 2. Amer. Physiol. Soc., Washington.

HAY M. F., CRAN D. G., MOOR R. M., 1976. Structural changes occuring during atresia in sheep ovarian follicles. Cell Tiss. Res., 169, 515-529.

HAY M. F., MOOR R. M., 1978. Changes in the Graafian follicle population during the follicular phase of the cycle. In LAMMING G. E., CHRIGHTON D. B., Control of ovulation. Butterworths, London (in press). 
INGRAM D. L., 1962. Atresia, 247-273. In ZUCKERMAN S., The ovary, vol. 1, Acad. Press, New York and London.

JONES E. C., 1970. Atresia in the ovaries of vertebrates. Bibliogr. Reprod., 15, 129-132, 245-247.

MOOR R. M., 1977. Sites of steroid production in ovine Graafian follicles in culture. J. Endocr., 73, 143-150.

MOOR R. M., TROUNSON A. O., 1977. Hormonal and follicular factors affecting maturation of sheep oocytes in vitro and their subsequent developmental capacity. J. Reprod. Fert., 49, 101-109.

NEKOLA M. V., NALBANDOV A. V., 1971. Morphological changes of rat follicular cells as influenced by oocytes. Biol. Reprod., 4, 154-160.

RAJAKOSKI E. 1960. The ovarian follicular system in sexually mature heifers with special reference to seasonal, cyclic and left-right variations. Acto endocr., Copnh., 34, (Suppl. 52), 1-68.

ZAMBONI L. 1972. Comparative studies on the ultrastructure of mammalian oocytes, 5-45. In BIGGERS J. D., SCHUETZ A. W., Oogenesis. Univ. Park Press, Butterworths, Baltimore and London. 